\title{
Aurora: Stereotyping and How It Shapes a Person's Perspective of His Own and Other People's Self-Identity
}

\author{
Siongkowinarto, Edwin \\ English Department, Faculty of Letters, Petra Christian University, Siwalankerto 121-131, Surabaya 602236, \\ East Java, INDONESIA \\ E-mails: tangled222@hotmail.com
}

\begin{abstract}
My screenplay Aurora follows a couple of high school students Dave and Aurora as they go out on their first date. With Dave being the high school nerd and Aurora being the popular girl, forming a bond obviously would not be easy. However, the story will peel back the layers of these two teenagers to the point that they realize that they are more than what their stereotypes suggest them to be. Since my work's main idea revolves around stereotyping and how people use it as a way to identify a person's character, hopefully it can emphasize to the audience the importance of not judging people based on their appearances without knowing them on a personal level. To be more specific, my screenplay will touch on stereotyping and how it shapes the main character Dave's perspective of his own and other people's self-identity. For that, I will use Charles Horton Cooley's Looking Glass-Self theory to showcase its effect on the characters on both physical and psychological level. Set in a couple's first date, the genre for my work will be teen romance. I see a lot of similarities in the genre's convention and opposites-attract storyline with my screenplay's subject

Keywords: Teen, Aurora, Teen Romance, Stereotyping, High School
\end{abstract}

\section{INTRODUCTION}

After long consideration, I finally decided to present my creative work in the form of a screenplay, with the idea of turning it into a movie. I feel that the screenplay style of writing suits my style of writing, which relies heavily on the dialogues rather than descriptions. I was inspired by one of my screenwriting idols Oscar-winning Aaron Sorkin, a screenwriter known as the master of dialogue, who likens a screenplay's dialogue to the sound of music, in that what is written in screenplay "is not meant to be read. It is meant to be performed" (Littlefield, 2013). Since the emphasis of my screenplay lies on the discussion between the characters, I felt that the story would have lesser emotional impact in printed format like novel. With that in mind, Sorkin's philosophy applies to my story, in a way that for the discussion to mean something to the audience, they need to be seen and heard through live-action performances. Experiencing the characters in the flesh and the discussion in real time mode will help the audience form stronger emotional attachment to what they do, say and how they connect with the people around them.

I think that the genre best suited for my screenplay would be the subgenre of the romance genre, which is teen romance. Romance itself is a genre that, "revolves around the love between two protagonists" (Buffam, n.d.), and, "explores an issue within love, including but not limited to: love at first sight, forbidden love, love triangle and sacrificial love" (Buffam, n.d.). Basically, the genre uses its story to explore the many facets of love through the eyes of its two protagonists (usually between male and female), like how characters perceive love and how love influences the way they approach a relationship. Only in this case, it explores the many facets of love specifically through the eyes of two teenaged protagonists, usually about the age of 13-19.

My screenplay aims to find out how stereotyping influences a person's perspective of his own self-identity as well as other people's self identity. Since the characters in the story are teenagers, I discover that stereotyping correlates heavily with teenagers in a way that it is a cross-generational struggle. Being included in a stereotype/ high school clique is so important to a teenager's coming-of- 
age in a way that, according to Children's Hospital child psychologist Linda Madison, they are able to "identify themselves with a group is part of deciding who they are and having a feeling of belonging" (Willis, 2017). At the same time, being excluded or being on the wrong end of it can create an adverse effect that, as described by violence prevention consultant Jay Bass, "those who cannot latch into certain groups are somewhat disenfranchised" (Willis, 2017). That can lead to constant bullying from peers, which often leads to something more extreme like suicide. For instance, on July $30^{\text {th }}$, 2017, I found an article in Detik.com regarding a high school student in Riau who drowned herself because of her classmates made fun of her "ugly duckling" look, something which she had no control of (Tandjung, 2017).

Such recent example highlights how the way high school works in terms of segregating a group of teenagers from other groups of teenagers still applies in today's world, which makes it easier for them to judge others based on their labels. It stretches back to the teenagers' tendency to give a label to their own self-identity, which if we go deeper is based on their personal struggle with identity crisis and fitting in with the society. A German-American psychoanalyst, Erik Erikson, even mentioned in the eight stages of a man's psychosocial development, that in the fifth stage, at an age of around 1218, a man's biggest desire in life is to discover "a sense of self and personal identity, through an intense exploration of personal values, beliefs and goal" (McLeod, 2017). An American psychologist, Helen L. Bee, further backs up Erikson's statement by saying that a man expects to come out of the stage with "a reintegrated sense of the self, of what one wants to do or be, and of one's appropriate sex role" (McLeod, 2017). In other words, an individual deems his search for a sense of self and personal identity a success once he feels like he belongs or fits in with the society, in this case amongst his high school peers. In other words, teenagers sees their stereotypes as the things that help define their personality as well as integrate them into the social world. Since teenagers see their stereotypes as both their personal and social identities, it also influences the way they judge other people's characters. To correlate the stereotyping subject matter with the teen romance genre, I decide to set the story on a couple's first date to address my point.

With that in mind, I think the most suitable target market for my screenplay would be teenagers, ranging between 13 to 19 years old. I am confident it will adhere more to this specific type of market because of its subject matter and premise. Despite its genre classification as a teen romance, my screenplay is in its core a discussion of teenage issues through the perspective of two teenagers. The fact that the beating heart of my story lies on the discussion itself and how it helps unveil to the audience characters' true personalities gives my screenplay an extra weight in the sense of its relevance to what is happening in today's world. Somehow, I believe that my story serves as a tribute to the type of struggle real-life teenagers go through. They will be able to find the situation and the characters presented in the story relatable to the ones they face and meet in their daily lives.

The statements of the problems in my screenplay are: why Dave judges his date, Aurora, solely based on her appearance, why judging Aurora solely based on her appearance hinders Dave from being his own self and why Dave changes when he is able to see Aurora beyond her stereotype. The purposes are to highlight the role of high school hierarchy in its tendency to put people in labels as it affects Dave's perception of his date, Aurora, Dave's lack of confidence with his own personality in hindering Dave from being himself in front of Aurora and Dave's more confident perception of his own personality in influencing his changing perception of Aurora.

For my screenplay's theory, I will use Charles Horton Cooley's the Looking Glass Self. Here, he argues that the self is actually a reflection of what others perceive of us. As stated in his book Human Nature and the Social Order, Cooley defines the self as "a somewhat definite imagination of how one's self - that is any idea he appropriates - appears in a particular mind, and the kind of a selffeeling one has is determined by the attitude towards this attributed to the other mind" (Cooley, 1902, p. 152). As much as one might admit that they are a separate individual in the sense that they can think and decide for themselves, Cooley begged to differ, saying that what makes the self the so-called separate individual originates from their surroundings. To help illustrate this point, Cooley puts the self in the position of someone standing in front of a mirror. On the one hand, what the person sees through 
a mirror is the same image of what appears before the mirror. On the other, what he/she sees is purely the mirror's perspective of the same image, not his/her perspective but designed to make the person feel as if it is. So often, people rely on this figurative mirror as a mode of self-discovery. In fact, who we are as a person is derived from our interactions with the society. Cooley would then classify the kinds of thoughts a person would have upon staring at that figurative mirror into three kinds, which will showcase my screenplay's two lead characters' growth from having no connection to a deeper one in the end.

Firstly, a person will most often consider "the imagination of our appearance to the other person" (Cooley, 1902, p.152). This is where the other person gets the slightest, on-the-surface idea of who we are, and therefore, he/she can only take the physical characteristics of what appears before $\mathrm{him} /$ her as reference. For instance, when what the other person sees before him/her is a skinny person wearing glasses and suspenders, the first thing that comes to his/her mind would be that the person standing in front of him/her is a nerd. An example of Cooley's first stage being applied to my screenplay showing how it fails to result in the characters having a connection with each other can be seen in beginning where Dave struggles to see Aurora's beautiful physique beyond her popular girl image, the same way Aurora sees Dave's skinny physique with his nerdy image. For this stage, however, even when Dave and Aurora have a deeper connection with each other, they still see each other physically as their stereotypes.

Secondly, a person will most often consider "the imagination of his/her judgment of that appearance" (Cooley, 1902, p.152). This stage is usually where the other person starts digging deeper. Now, the other person gets a bigger picture of who we are, and therefore, he/she can take the personalities of what appear before him/her into account. By this stage, the other person can more or less draw a conclusion about that person. For instance, the other person may dislike that person for being a nerd and weird. An example of Cooley's second stage applied to my screenplay showing how it fails to result in the characters having a connection with each other can be seen in moments before and during their date where Dave finally gets the sense that a popular girl Aurora is a rich girl who likes only fancy stuffs and attractive boys, hence the impression that she is out of his league. Same goes with Aurora, who thinks that the nerdy Dave is a subpar guy who lacks the kind of social skills, attractive looks and lofty reputations her ex-boyfriends or even her high school peers possess, hence the impression that Dave is weird. For this stage, however, when Dave and Aurora have a deeper connection with each other, their views regarding their stereotypes and their opposite halves change. Aurora finds out that Dave is actually a romantic. Dave also finds out that Aurora is actually a more complicated, sympathetic girl.

Thirdly, a person will consider "some sort of feeling, such as pride or mortification" (Cooley, 1902, p.152). Different from the previous two stages where the other person is the subject and the self is the object, here, it is the other way around. This is where the other person begins to hand the control over to us, leaving us to weigh in at what the other person thinks of us on a physical and personal level, like a self-evaluation. For example, after learning that a person with a skinny figure and wearing glasses and suspenders is considered both a nerd and weird, and that the other person dislike the person for being that, then the person may come up with the conclusion that he/she must change his/her physique or behavior for the other person to like him/her. An example of Cooley's stage being applied to my screenplay showing how it fails to result in the characters having a connection with each other can be seen in the way Dave and Aurora approach their dinner date in the Italian restaurant. To avoid being weird, Dave decides to ditch his nerdy behavior and imitate the cool kids, and as for Aurora, to avoid looking like she is out of Dave's league, she decides to be more tolerant. For this stage, however, when Dave and Aurora have a deeper connection with each other, their actions towards their stereotypes and their opposite halves change. Dave decides to embrace his more romantic self, and Aurora with her more complicated, sympathetic self. In other words, they respond by being themselves.

For the methodology, I used two kinds of research, which are the primary and secondary research. For the primary research, I use the story of my old high school friend and his girlfriend as my 
main reference. I met them during a holiday in Singapore, and amazingly, they are still together even after they graduated high school. They had their down times with their relationship in Surabaya, but they agree that the unfamiliar environment of Singapore helped them become closer. Also, the fact that the only familiar face my old friend and his girlfriend sees in Singapore is practically each other open their eyes on the importance of a significant other in their lives. Their story inspires my decision to not feature a high school building as the setting, even though the main characters are high school students. Beyond that, I also observed modern-day teenagers anywhere I go to get the true feel of the way teens talk and the types of issues they discuss.

For the secondary research, I consulted with various books and articles. For instance, I discovered the Looking Glass Self theory through Charles Horton Cooley's book Human Nature and the Social Order, the genre conventions through Catherine Driscoll's book Teen Film: A Critical Introduction, and a screenplay writing guidebook with Ray Frensham's Teach Yourself: Break into Screenwriting $5^{\text {th }}$ Edition. Books aside, since I am writing a screenplay, I also used films as reference. Two titles then stood out for me: The Breakfast Club (Manning, Tanen \& Hughes, 1985) and the Before trilogy (Before Sunrise (Walker-McBay \& Linklater, 1995), Before Sunset (Walker-McBay \& Linklater, 2004) \& Before Midnight (Konstantakopoulos, Woodhatch \& Linklater, 2013)). The Breakfast Club influences my screenplay's thematic beats in terms of teen issues being the main discussion in the story. The Before trilogy influences the more meandering, dialogue-driven structure in my screenplay's storytelling.

OUTLINE OF THE CREATIVE WORK length.

My creative work will come in the form of a feature-length screenplay of about 104 pages in

\subsubsection{Theme}

For the theme, my work is trying to convey that stereotyping shapes an individual's perspective of his self-image and other individual's self-image. I want to show the struggle the main character Dave goes through with stereotypes, not only the way he perceives himself but the way he perceives others, in this case his date Aurora.

2.2.2.2.

Pitch

a. Dave is a high school student who has a crush on a fellow student Aurora, and, after helping Aurora's older brother Vinny out with school work, in return asks Vinny to convince Aurora to go out on a date with him, a dream that suddenly comes true.

b. Early into his first date, Dave has difficulty connecting with her due to his shy demeanor and Aurora's dismissive demeanor towards him.

c. Dave finally finds a connection to the point that he makes Aurora warm more to him, and as he takes her home, finally braves himself to ask Aurora out on a second date, to which Aurora says yes.

\subsubsection{Synopsis}

Dave picks up Aurora, his high school crush, from her house for their first date. Dave rings on her doorbell and is greeted by Aurora's older brother Vinny. Dave and Vinny have a brief conversation while Aurora is still inside, getting ready. It is revealed that the reason Dave lands the date of his dream because he helped Vinny with some school assignments. After talking for awhile, Aurora finally shows up. Despite dressing well for the occasion, Aurora is actually less enthusiastic about following Vinny's advice in dating Dave, fearing the negative impact it can give to her high school reputation. But, for one night, she agrees to give Dave a chance.

For the first few hours, the date goes on rather awkwardly. First, on the way over to the fancy European restaurant Vinny had suggested to him during their brief conversation at the house, Dave's car ran out of gas, forcing them to push the car all the way to the gas station. This gives Aurora 
an early bad impression. Second, once the couple arrived at the restaurant, Dave's attempt at following Vinny's advice to be a "cooler version" of himself gets in the way of him establishing a connection with Aurora, who is much more interested in playing with her phone. Even after they finish their dinner, the couple still regards each other throughout with awkward glances and conversations, but mostly silence. Fed up, Aurora threatens to leave, and then Dave tries convincing her to give him another chance, blaming Vinny's advice for their awkward date in the restaurant. Finally, she agrees.

For the rest of night, Dave and Aurora spend their time visiting various places around Bali. At last, when they made a stop at the beach, they open up about each other. It turns out that Dave's insecurity with girls is derived from once being rejected by his crush in middle school. At the same time, Aurora admits to feeling uncomfortable living life as the most popular girl in school, revealing a story about how she was forced by her peers to bully a former student until she committed suicide. As they continue to bond, to the point that they finally develop feelings for each other, she receives a call from a friend, finding out that Vinny is hosting a party in her house. Aurora begs Dave to drive her home, but Dave tries to resist. Dave reveals that he knows of the party, and that his brother begged him to stay silent about it so that he can keep her out of the house for the night. Angered, she leaves. Dave follows in pursuit.

Finally, they go back to Aurora's home and find it in a state of disarray. Aurora goes back to her house while, under Aurora's insistence, Dave is forced to stay in the car. Restless, Dave steps out of the car and enters the house. He finds Aurora, being sexually harassed by her ex-boyfriend Dylan. Dave impulsively lunges at Dylan. Dave and Dylan had a brief fight, which ends with Dave being knocked unconscious.

Dave wakes up and finds himself in Aurora's bedroom, with Aurora treating his wounds. Dave confesses his feelings to Aurora, and hints at a second date. Aurora then confesses that she enjoys spending the night with Dave, but fear of how their newfound relationship could affect both her and Dave's high school reputation. However, Dave convinces her otherwise and in the end, Aurora agrees to go on a second date with him.

2.2.2.4.

Characters

- Dave Winarto, 17

Dave is the typical high school nerd, a skinny teen who wears a knitted vest and a 50's style horn-rimmed glasses and is a perennial high achiever. Yet, that also means he is an underachiever in terms of social skills. His lowly status amongst the high school hierarchy alone makes him feel shy and insecure about himself. His anxiety level is further elevated when he lands the date with Aurora, the girl he has been crushing. He clearly has feelings for her, despite his awareness that she will reject him at a first glance. For a moment, it feels as if his fear would be realized when his material and physical ordinariness or lack thereof fails to impress her. However, his shy demeanor actually masks over his true self, which is a romantic person. When that side of him finally comes to the fore, Aurora starts warming up to Dave a bit. This does not only give him confidence to talk to Aurora, but also helps alter his perspective about his own stereotype as well as his date.

- Aurora Almira, 17

Aurora is Dave's love interest and Vinny's younger sister. She is the archetypal popular girl in school, with the long, wavy black hair, exotic skin and the Victoria Secret's model physique. Belonging in the upper end of the high school hierarchy, she is basically the girl the guys stop and stare every time she walks down the hall. She cherishes every moment she is the center of attention, yet her high reputation also creates an emotional turmoil within her. She considers herself a person who can make decisions for herself, yet she often let her reputation makes the decisions for her. Such turmoil rears its heads once more when she is forced to go out on a date with the school nerd 
Dave. She is aware that dating Dave will kill her reputation, and the most popular girl thing she can do is to act mean and disrespectful towards Dave. However, once she gets to know Dave better, once she lets her true personality make the decision for her, it turns out that she actually enjoys Dave's company, and in the process, alters her perspective of her own perspective as well as Dave's.

\section{- Vinny, 18}

Vinny is Aurora's older brother. He is pretty much the cool, easygoing type teen who finds it easy when it comes to conquering a woman's heart. He is an underachiever, which is why he enlisted Dave to help him finish 12th grade. From then on, he and Dave became close friends, and later, the matchmaker for Dave's date with Aurora. Reckless at times with his party boy image, he is actually a kind-hearted person, kind enough to help Dave with his date through his advice, even if it does not always work.

\subsubsection{Setting}

I selected Bali as the location for my story because of its adventurous vibe. As much as stereotyping serves as the story's main subject matter, it is atmospherically about two teenagers trying to escape from the shackles of their high school lives, and setting their escape against Bali's urban-meets-natural backdrop would give the story and message a more effective pay-off than in urban places like Jakarta or Surabaya. As to how it will pan out in my screenplay, it is going to start off in Aurora's house, a fancy, two storey beach house in the suburbs where Dave will pick her up for the date. Then the story will take the audience to various places around Bali following their first date, from a fancy European restaurant (Jamie's Italian Kuta), the local stalls, a traditional side street restaurant (Legian Kuta Bali) and then the beach.

\section{CONCLUSION}

4.1.

\section{Concluding Thoughts}

For this chapter, I would like to restate the three purposes of my creative work I had established prior to the screenwriting process and how key points in the screenplay correlate with these purposes.

Firstly, my purpose of creating the screenplay Aurora is to highlight the role of the high school social hierarchy in its tendency to put people in labels as it affects the main character Dave's perception of his date Aurora, which my work depicts quite clearly. One example can be seen in the beach scene right around the third act when Dave, bemused by Aurora saying that she is offended by the whole high school stereotype thing, argues with Aurora. He starts comparing his high school life to Aurora's, protesting how people in school treats him like dirt despite his intelligence while implying that Aurora only needs to do as little as "flip her hair" to earn people's respect.

Secondly, my purpose of creating the screenplay Aurora is to highlight Dave's lack of confidence with his own personality in hindering Dave from being himself in front of Aurora, which my work depicts quite clearly. One example can be seen in the beginning of the screenplay, when Dave is talking to Vinny at the front porch, Dave keeps on saying that the things he did for Vinny does not warrant a date with the most popular girl in school. Even as Vinny kept on insisting that he owed a debt of gratitude to Dave, he keeps belittling his own achievement, even going as far as saying, "it's not as if I saved her from a fire or something."

Last but not least, my purpose of creating the screenplay Aurora is to highlight Dave's more confident perception of his own personality in influencing his changing perception of his date Aurora, which my work depicts quite clearly. One example can be seen in the car scene, right after Dave and Aurora left the Italian restaurant. Aurora stumbled across stacks of old cassettes in Dave's car's glove compartment. Dave is ready to be torn apart by Aurora's criticism, but the fact that Aurora then says that the cassette thing was cool instill confidence of his ability to impress a girl his own way.

\subsection{Lessons Learned}


I learned a lot during my time writing this screenplay. I found crafting a teen romance story that stands out above the others challenging, which I overcame by staying true to the genre's formulas whilst subverting the tropes. Then, I found writing natural dialogues as well as delivering a coherent story around them pretty difficult at first, which I overcame by expanding my research beyond movies and brainstorming the type of subject matters I should include and classifying them to make sure it builds up on a storytelling standpoint. I also had trouble with time management, which I overcame by write as much as possible and think of organizing later.

\section{3. $\quad$ Future Plans}

Obviously, I am interested in expanding my horizon as a screenwriter, be it by trying to tackle a wide variety of genres, big-budget project or even for once, setting aside writing original screenplay for an adapted screenplay, but most of all, I really hope someday film producers are interested in turning my screenplay Aurora into a feature-length production.

\section{REFERENCES}

Buffam, N. (2011, March 26). Romance. Retrieved from https://thescriptlab.com/screenplay/genre/994-romance-sp-1570419489/

Cooley, C.H. (1902). Human nature and the social order. Retrieved from https://archive.org/details/humannaturesocia00cooluoft

Konstantakopoulos, C.V., Woodhatch, S. \& Linklater, R. (Producers), \& Linklater, R. (Director). (2013). Before midnight [Motion Picture]. United States: Sony Pictures Classics.

Littlefield, K. (2013, July 1). Sorkinese. Retrieved from https://www.writermag.com/2013/07/01/aaron-sorkin/

McLeod, S. (2017). Erik Erikson. Retrieved from https://www.simplypsychology.org/ErikErikson.html

Tandjung, A.C. (2017, July 31). Diduga korban bully di sekolah, sekolah siswi di Riau bunuh diri. Retrieved from https://news.detik.com/berita/d-3581066/diduga-korban-bully-di-sekolahsiswi-sma-di-riau-bunuh-diri

Tanen, N., \& Hughes, J. (Producers), \& Hughes, J. (Director). (1985). The breakfast club [Motion Picture]. United States: Universal.

Walker-McBay, A., (Producer), \& Linklater, R. (Director). (1995). Before sunrise [Motion Picture]. United States: Columbia.

Walker-McBay, A., \& Linklater, R. (Producers), \& Linklater, R. (Director). (2004). Before sunset [Motion Picture]. United States: Warner Independent.

Willis, M. T. (2017, November 27). When good groups go bad. Retrieved from https://abcnews.go.com/Health/story?id=117097\&page $=1$ 